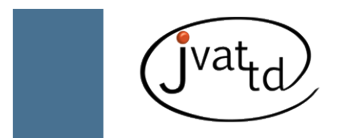

\title{
Treatment of venous ulcers with fibrin sealant derived from snake venom
}

\author{
Gatti MAN (1), Vieira LM (1), Barraviera B (2, 3), Barraviera SRCS $(3,4)$
}

(1) Health Education Clinic, CEPS, Sacred Heart University, USC, Bauru, São Paulo State, Brazil; (2) Department of Tropical Diseases and Imaging Diagnosis, Botucatu Medical School, São Paulo State University (UNESP - Univ Estadual Paulista), Botucatu, São Paulo, Brazil; (3) The Center for the Study of Venoms and Venomous Animals, CEVAP, São Paulo State University (UNESP - Univ Estadual Paulista), Botucatu, São Paulo, Brazil; (4) Department of Dermatology and Radiotherapy, Botucatu Medical School, São Paulo State University (UNESP - Univ Estadual Paulista), Botucatu, São Paulo, Brazil.

\begin{abstract}
Venous ulcers of the lower limbs complicated by infection or chronicity represent a serious public health problem. The elevated number of those afflicted burdens the health services, interferes in quality of life and causes absenteeism. Although there are 2,500 items on the market, ranging from the simplest dressing up to the most complex types of dressing, treatment remains a challenge. Among the substances used, fibrin sealant is the one that promotes diminution of bacterial colonization and of edema, controls hemorrhaging, alters the pain threshold by protecting the nerve endings, hydrates the wound bed and forms granulation tissue that favors healing. Its disadvantages include higher cost and utilization of human fibrinogen that can transmit infectious diseases. The Center for the Study of Venoms and Venomous Animals (CEVAP) at São Paulo State University (UNESP) developed a new sealant made up of fibrinogen extracted from large animals and from an enzyme obtained from snake venom. The present study, developed in the Health Education Clinic (CEPS) of Sacred Heart University (USC) aimed to evaluate the effect of the new sealant on the healing process of venous ulcers in 24 adult patients, seven of whom were male and 17 female. Two study groups were formed as follows: Group 1 (G1) - control group of 11 patients treated with essential fatty acid (EFA) and Unna's boot, and Group 2 (G2) - 13 patients treated with essential fatty acid (EFA), fibrin sealant and Unna's boot. The follow-up lasted eight weeks and the sealant was applied at only the first and fourth weeks. The results showed that Group 2 presented worse lesion conditions as to healing, but, when comparing the two groups, it was noteworthy that the the sealant was effective in healing venous ulcers. There is evidence that the new sealant is recommended for leg ulcers with the following advantages: ease of application, preparation of the wound bed, diminution of pain and a higher number of discharges in the eighth week. More important, other positive characteristics are non-transmission of infectious diseases, absence of adverse reactions, and economic advantage of being produced by Brazilian technology. Finally, it is suggested that the weekly application of sealant, for at least eight weeks, could improve the healing process and consequently life quality.
\end{abstract}

Key words: fibrin sealant, healing, wounds, venous ulcers.

Ulcers can be defined as any lesion present in the epithelial tissue, in mucosa or in certain organs, impairing their basic functions (1). They are characterized by a loss of tissue adjacent to the epidermis, sometimes the dermis and in many cases reaching the subcutaneous cellular tissue and less often the muscles (1).

In general, they appear in the inflammatory or proliferative phase of the process, but some characteristics hinder healing, such as the accumulation of metalloproteinases, collagenases and elastases. These molecules degrade the collagen and growth factors thus hampering epithelialization; they even develop a microenvironment with low oxygen tension which brings about the proliferation of fibroblasts 
and consequently the augmentation of tissue fibrosis. Chronic ulcers tend to be colonized by infectious agents including bacteria and fungi, thus delaying healing (2).

The chronic ulceration of the lower limbs - a more advanced stage of chronic venous disease (CVD) - afflicts a large portion of the adult population and causes significant economic and social impact in addition to changing the quality of life (3). It represents a public health problem in Western countries whose prevalence varies between 0.06 and $2 \%$ being higher than $4 \%$ in individuals above 65 years of age (4-8). Fowkes et al. (3), reviewing the literature on the adult population (aged more than 18 years) in Western countries, found a prevalence of $0.3 \%$, that is, approximately one case out of 350 individuals.

In the United States, the annual cost of this treatment is estimated at between 1.9 and 2.5 billion dollars. CVD represents one of the ten most common reasons for seeking medical attention in that country (7). In the United Kingdom, $1.3 \%$ of the health budget is invested in the treatment of venous ulcers (6). In Brazil, Castro and Silva (9) described how CVD, in its diverse clinical presentations, ranks fourteenth among causes absenteeism. It may provoke cutaneous alterations, including ochre dermatitis, lipodermatosclerosis and ulcers, and is associated with dysfunction of the calf muscle pump whose primary function is to promote the venous return of blood from the lower limbs $(10,11)$. The pump is composed of calf muscles; deep, superficial and communicating venous system.

Such pump dysfunction can be a result of venous obstruction (primary or postthrombotic), insufficiency of perforating veins, arteriovenous fistulas, neuromuscular dysfunction or a combination of these factors (12). The two principal causes of dysfunction are primary varicose disease and the late effects of deep vein thrombosis (DVT) (13).

Venous ulcers tend to occur slowly, with traumatisms in the lower limbs being the principal triggering factors. Varicose veins are present in the majority of patients, although some may have a history of prior episodes of deep vein thrombosis (DVT).

In general, a venous ulcer is initially irregular and superficial, but can become deep with well defined borders and yellowish exudate. It may be singular or multiple and of variable sizes and locations, but normally it occurs in the distal portion of the lower limbs, particularly in the region of the medial malleolus (7).

The principal complications that occur in patients with chronic venous ulcers are: infections of soft tissues, critical colonization, contact dermatitis, osteomyelitis and less often neoplastic changes (14).

The main methods to promote healing are local treatment and compression therapy. The latter acts in macrocirculation, augmenting the venous return and the ejection volume, in turn activating the calf muscles and diminishing the reflux during walking (11). The compression increases the tissue pressure thus favoring the reabsorption of edema and improving lymphatic drainage; in microcirculation it acts by diminishing the release of liquids and macromolecules to the interstice, also stimulating of fibrinolytic activity $(15,16)$.

In local treatment the preparation of the wound bed is very important (17). Falanga (18) stated that it is inappropriate to utilize sophisticated expensive products in poorly prepared wounds. A wound must have at least one well-vascularized bed, a minimum quantity of bacteria and little or no exudates before an effective result can be obtained. Preparing the bed involves the control of at least four steps, identified as "TIME" treatment of tissue, control of inflammation and infection, maintenance of humidity and advance of the epithelial margins $(19,20)$.

There are about 2,500 items on the market aimed at treating acute and chronic wounds, from the simplest dressing to the most complex types of dressing that actively interfere in the diverse phases of the healing process $(21,22)$.

Among the substances utilized, fibrin sealant is one of the best alternatives. It is made up of bovine thrombin and human fibrinogen, promotes the diminution of infection and of edema, controls hemorrhaging, alters the pain threshold by protecting nerve endings, ensures hydration of the wound bed and promotes the formation of granulation tissue, thus favoring healing $(23,24)$. Despite the precautions taken by the manufacturers, the risk of transmission of new viruses, or even of the transmission of previous ones - since the laboratory exams do not detect them - continues to the present day. Furthermore, the elevated costs of the sealant render its routine use among our patients unviable.

The Center for the Study of Venoms and 
Table 1. Ulcer depth in the studied groups

\begin{tabular}{c|c|c|c|c|c|c}
\hline \multirow{2}{*}{ Groups } & \multicolumn{2}{|c|}{ G1 (control) } & \multicolumn{2}{c|}{ G2 (sealant) } & \multicolumn{2}{c}{ TOTAL } \\
\hline & Number & $\%$ & Number & $\%$ & Number & $\%$ \\
\hline Superficial & 8 & 72.73 & 4 & 30.77 & 12 & 50.00 \\
\hline Deep and with cavities & 3 & 27.27 & 9 & 69.23 & 12 & 50.00 \\
\hline Total & 11 & 100.00 & 13 & 100.00 & 24 & 100.00 \\
\hline
\end{tabular}

$\mathrm{G} 1 \times \mathrm{G} 2, \mathrm{p}=0.041$.

Venomous Animals (CEVAP) at São Paulo State University (UNESP) developed a new sealant made up of fibrinogen extracted from large animals and an enzyme obtained from snake venom. Such non-utilization of human blood not only avoids the transmission of infectious diseases but also reduces cost since it is manufactured in Brazil (25).

In the present study, 24 adult patients, seven males and 17 females, were evaluated. They presented ulceration of the lower limbs of venous origin. Two study groups were formed as follows: Group 1 (G1) - control group of 11 patients treated with essential fatty acid (EFA) and Unna's boot, and Group 2 (G2) - 13 patients treated with essential fatty acid (EFA), fibrin sealant and Unna's boot. The weekly follow-up lasted eight weeks and the sealant was applied at the first and fourth weeks, respectively.

The inclusion criteria were defined as follows: having a diagnosis of venous ulcer of a lower limb for less than five years in any phase of healing, being available to receive the dressing once a week, having undergone or not any type of prior treatment and accepting the research conditions by signing terms of free and informed consent. The adopted criteria for exclusion were: having an associated arterial disease, not adhering to the treatment and not accepting the use of Unna's boot.

The project was submitted to the Research Ethics Committee of Sacred Heart University, registered under the protocol number 50/06, and approved on August 17, 2006. The results show that the patients of G2 presented a higher percentage of deep wounds and cavities, as showed in Table 1.

It could be observed that the patients treated with the new sealant presented wounds in worse conditions than those of the control group. Even so, five participants in G1 and seven in G2 evolved to good healing. Furthermore, it was clear that the capacity to prepare the wound bed led to diminution of pain and allowed the patients discharge at the eighth week of treatment. Based on these preliminary results the authors suggest that the weekly application of sealant, for at least eight weeks, could improve the healing process and raise the cure rate (26).

In conclusion, given that ulcers are a public health problem for Western countries including Brazil, new studies are needed to develop cheaper and more efficient treatment. Due to the fact that the present work was designed to be a phase I clinical trial, multicenter studies with a greater number of patients should be conducted to evaluate the ideal schedule to apply this new sealant.

\section{COPYRIGHT}

(c) CEVAP 2011

\section{SUBMISSION STATUS}

Received: February 17, 2011.

Accepted: March 30, 2011.

Abstract published online: April 6, 2011.

Full paper published online: May 31, 2011.

\section{CONFLICTS OF INTEREST}

There is no conflict.

\section{FINANCIAL SOURCE}

The Health Education Clinic (CEPS) of Sacred Heart University (USC) provided the financial grants.

\section{ETHICS COMMITTEE APPROVAL}

The present study was approved by the Research Ethics Committee of Sacred Heart University (USC), under the protocol number 50/06, on August 17, 2006. 


\section{CORRESPONDENCE TO}

\section{MÁRCIA APARECIDA NUEVO GATTI,}

Universidade do Sagrado Coração, Rua Irmã

Arminda, 10050, Bauru, SP, 17011-160, Brasil.

Email:marcia.gatti@usc.br.

\section{REFERENCES}

1. Sampaio SAP, Rivitti EA. Glossários Dermatológicos. In: Sampaio SAP, Rivitti EA, editors. Dermatologia. $2^{\text {nd }}$ ed. São Paulo: Artes Médicas; 2000. p. 71-8.

2. Falanga V. The chronic wound: impaired healing and solutions in the context of wound bed preparation. Blood Cells Mol Dis. 2004;32(1):88-94.

3. Fowkes FG, Evans CJ, Lee AJ. Prevalence and risk factors of chronic venous insufficiency. Angiology. 2001;52(Suppl 1):S5-15.

4. Bergqvist D, Lindholm C, Nelzen O. Chronic leg ulcers: the impact of venous disease. J Vasc Surg. 1999;29(4):752-5.

5. Evans CJ, Fowkes FG, Ruckley CV, Lee AJ. Prevalence of varicose veins and chronic venous insufficiency in men and women in the general population: Edinburgh Vein Study. J Epidemiol Community Health. 1999;53(3):149-53.

6. Callam MJ. Epidemiology of varicose veins. Br J Surg. 1994;81(2):167-73.

7. Valencia IC, Falabella A, Kirsner RS, Eaglstein WH. Chronic venous insufficiency and venous leg ulceration. J Am Acad Dermatol. 2001;44(3):401-21.

8. Callam MJ, Ruckley CV, Harper DR, Dale JJ. Chronic ulceration of the leg: extent of the problem and provision of care. Br Med J. 1985;290(6485):1855-6.

9. Castro e Silva M. Chronic venous insufficiency of the lower limbs and its socio-economic significance. Int Angiol. 1991;10(3):152-7.

10. Gross EA, Wood CR, Lazarus GS, Margolis DJ. Venous leg ulcers: an analysis of underlying venous disease. $\mathrm{Br}$ J Dermatol. 1993;129(3):270-4.

11. Zimmet SE. Venous leg ulcers: modern evaluation and management. Dermatol Surg. 1999;25(3):236-41.

12. Abbade LP, Lastoria S. Venous ulcer: epidemiology, physiopathology, diagnosis and treatment. Int J Dermatol. 2005;44(6):449-56.
13. Becker F. Mechanisms, epidemiology and clinical evaluation of venous insufficiency of the lower limbs. Rev Prat. 1994;44(6):726-31.

14. Phillips TJ, Dover JS. Leg ulcers. J Am Acad Dermatol. 1991;25(6 Pt 1):965-87.

15. Partsch H. Compression therapy of the legs. A review. J Dermatol Surg Oncol. 1991;17(10):799-805.

16. Smith PC, Sarin S, Hasty J, Scurr JH. Sequential gradient pneumatic compression enhances venous ulcer healing: a randomized trial. Surgery. 1990;108(5):871-5.

17. Dealey C. Cuidando de feridas: um guia para as enfermeiras. $3^{\text {rd }}$ ed. São Paulo: Atheneu; 2008.

18. Falanga V. Classification for wound bed preparation and stimulation of chronic wounds. Wound Repair Regen. 2000(8):347-52.

19. Sibbald RG, Orsted H, Schultz GS, Coutts P, Keast D. Preparing the wound bed 2003: focus on infection and inflammation. Ostomy Wound Manage. 2003;49(11):23-51.

20. Romanelli M, Flanaga M. Depois da TIME: preparação do leito da ferida nas úlceras de pressão [Oct 18 2008]. Available at: www.ewma.org.

21. Cândido LC. Nova abordagem no tratamento de feridas. São Paulo: SENAC; 2001.

22. Cuzzel J, Krasner D. Feridas: tratamento e cicatrização. In: Gorgia P, editor. Curativos. Rio de Janeiro: Revinter; 2003. p. 103-14.

23. Hayward PJ, Mackay IS. Fibrin glue in nasal septal surgery. J Laryngol Otol. 1987(101):133-8.

24. Volkov A, Radev I. The use of autologous fibrin adhesive in septoplasty. Vestn Otorinolaringol. 1996(1):45-7.

25. Barros LC, Ferreira Junior RS, Barraviera SRCS, Stolf HO, Thomazini-Santos IA, Mendes-Giannini MJS, Toscano E, Barraviera B. A new fibrin sealant from Crotalus durissus terrificus venom: applications in medicine. J Toxicol Environmental Health, Part B, 2009;12(8):553-71.

26. Gatti MAN. Treatment of venous ulcers with surgical adhesive derived from snake venom. J Venom Anim Toxins incl Trop. Dis. 2009;15(2):368. 